\title{
Respiratory pathogenesis of amoebic gill disease (AGD) in experimentally infected Atlantic salmon Salmo salar
}

\author{
M. J. Leef ${ }^{1, *}$, J. O. Harris ${ }^{1,2}$, M. D. Powell ${ }^{1}$ \\ ${ }^{1}$ School of Aquaculture, Tasmanian Aquaculture Fisheries Institute, University of Tasmania and Aquafin CRC, \\ Locked Bag 1-370, Launceston, Tasmania 7250, Australia \\ ${ }^{2}$ Present address: Faculty of Science and Engineering, School of Biological Sciences, Flinders University of South Australia,
} GPO Box 2100, Adelaide, South Australia 5001, Australia

\begin{abstract}
The aim of this study was to investigate the respiratory responses of Atlantic salmon, Salmo salar, experimentally affected with amoebic gill disease (AGD). In Series I, arterial blood samples were taken over a $96 \mathrm{~h}$ period following amoebae addition to examine potential respiratory effects associated with initial exposure. No major significant treatment effects were found between fish exposed to amoebae and control (non-exposed) fish. Arterial $\mathrm{pH}\left(\mathrm{pH}_{\mathrm{a}}\right)$ was seen to be significantly elevated at $48 \mathrm{~h}$ in AGD fish relative to the $0 \mathrm{~h}$ time point. To investigate the long-term respiratory effects associated with infection, fish were similarly exposed to amoebae and sampled over a $16 \mathrm{~d}$ period. As for Series I, caudal blood pH was significantly elevated by Day $2(48 \mathrm{~h})$ compared to the pre (Day 0)-time point, suggesting that initial exposure to amoebae and/or amoebae attachment may have induced an initial respiratory alkalosis via increased ventilation frequency and/or amplitude. From Day 7 onwards, and coinciding with a significant increase in the percentage of affected gill filaments, blood $\mathrm{pH}$ decreased significantly, possibly indicating the onset of the characteristic respiratory acidosis that has previously been described for experimentally AGDaffected Atlantic salmon. Although fish in this study showed up to $90 \%$ AGD-affected filaments, the corresponding respiratory results do not reflect a major acid-base disturbance. Therefore, the findings from the present study support the contention that, although AGD only affects the gill, AGDassociated mortality in Atlantic salmon may not be primarily associated with respiratory failure.
\end{abstract}

KEY WORDS: Atlantic salmon · Salmo salar · Amoebic gill disease · AGD · Neoparamoeba pemaquidensis $\cdot$ Respiration $\cdot$ Pathogenesis

\section{INTRODUCTION}

Amoebic gill disease (AGD) is currently the most significant health issue affecting the production of Atlantic salmon Salmo salar in Tasmania (Munday et al. 1990). The causative agent, Neoparamoeba pemaquidensis, formerly known as Paramoeba pemaquidensis, was first described in sea-pen-reared coho salmon Oncorhynchus kisutch (Kent et al. 1988). Seemingly ubiquitous in nature, this amoeba is presumed to be responsible for AGD outbreaks in a number of countries, including Ireland, USA, Chile, Australia and New Zealand, and also in a number of species, includ- ing Atlantic salmon, rainbow trout O. mykiss (Munday et al. 1990), coho salmon (Kent et al. 1988), turbot Scophthalmus maximus (Dykova et al. 1998) and seabass Dicentrarchus labrax (Dykova et al. 2000, reviewed by Munday et al. 2001, Nowak et al. 2002).

In all species studied to date, the gill has been the only site of infection, with gross signs of infection indicated by slightly raised mucoid patches on gills. These patches are present histologically as multifocal hyperplastic lesions, generally resulting in the fusion of secondary lamellae (Munday et al. 1993, Adams \& Nowak 2001, 2003, 2004). AGD-associated mortality has been presumed to be associated with a respiratory distur- 
bance, as both lethargy and respiratory distress have been described from salmonid AGD infections (Kent et al. 1988). Despite this, experimental studies have not been able to conclusively confirm respiratory failure as the physiological mode of action responsible for mortality (Powell et al. 2000, Fisk et al. 2002).

Clinical investigations have found that, although gill functional area may be compromised, affected fish do not suffer hypoxemia, although pronounced acid-base disturbances have been reported (Powell et al. 2000). Hypoxic challenge experiments suggested that infection with AGD resulted in a mild impediment of gas transfer under normoxic conditions that leads to a characteristic acidosis (Powell et al. 2000). When fish affected with AGD are challenged, i.e. during hypoxia, a redistribution of blood flow within the gill, lamellar recruitment and/or changes in branchial vascular resistance compensate for the reduction of functional gill surface area, therefore allowing the fish to defend respiration (Powell et al. 2000, Fisk et al. 2002). Although fish affected with AGD are commonly seen to undergo this acidosis, the actual onset and pathogenesis of the respiratory disturbance has not been examined.

The present study was designed to track the respiratory responses and, more specifically, the onset of acidosis in Atlantic salmon exposed and subsequently infected with Neoparamoeba pemaquidensis. In order to document the respiratory pathogenesis, the present study has aimed to investigate the respiratory effects associated with both initial amoebae exposure and subsequent amoebae attachment leading to the development of characteristic gill lesions. An additional experiment was conducted to assess respiratory changes over a longer time period, in which case the level of AGD severity, based upon histological analysis, could be associated with respiratory effects.

\section{MATERIALS AND METHODS}

Fish, husbandry and maintenance. Atlantic salmon of approximately $750.7 \pm 22.8$ and $52.4 \pm 1.2 \mathrm{~g}$ (mean \pm SEM) (Series I and II, respectively) were obtained from a commercial salmon farm and acclimated to laboratory conditions in a 40001 recirculating system for at least $4 \mathrm{wk}$ prior to experimental use. Throughout the acclimation period the fish were held under a natural photoperiod in re-circulating, full-strength seawater (35\%) at approximately 15 to $16^{\circ} \mathrm{C}$ and were fed daily to satiation using a commercial food pellet (Atlantic Salmon Grower LE, Skretting). Feeding was ceased for Series I fish at least $1 \mathrm{~d}$ prior to surgical procedures. Series II fish were fed continuously throughout the experimental period.
Surgical procedures and infection protocol. Series I: Fish were anaesthetised with clove oil $\left(0.03 \mathrm{ml} \mathrm{l}^{-1}\right)$ and transferred to a surgical table where the gills were constantly irrigated in a retrograde direction with a chilled, aerated seawater, anesthetic solution, containing $0.01 \mathrm{ml} \mathrm{l}^{-1}$ clove oil. Following placement of a dorsal aortic catheter, implanted according to the method of Soivio et al. (1975) and filled with modified Cortland's saline (Wolf 1963, containing $160 \mathrm{mmol} \mathrm{l}^{-1} \mathrm{NaCl}$, after Milligan et al. 1991), fish were transferred to individual 51 , black-acrylic respirometer boxes, supplied with recirculated fullstrength seawater (total system $7501,16^{\circ} \mathrm{C}, 90$ to $100 \%$ $\mathrm{O}_{2}$ saturation, $\mathrm{pH} 8.0$ to 8.2). Fish were left to recover for 20 to $24 \mathrm{~h}$ before experimentation. Following recovery, the 7501 system containing the respirometer boxes was partially closed for $6 \mathrm{~h}$ to create a recirculating volume of $100 \mathrm{l}$. To this volume, either 10000 amoeba cells $\mathrm{l}^{-1}$, isolated from the gills of clinically infected fish according to the method of Howard \& Carson (1993) (AGD), or, in the case of controls (CON), sterile, filtered seawater was added.

Series II: For experimental purposes fish were placed in a modular tank system (total system 2750 l, $16^{\circ} \mathrm{C}, 90$ to $100 \% \mathrm{O}_{2}$ saturation, $\mathrm{pH} 8.0$ to 8.2 ) comprising 3 separate tanks and were left to acclimate for approximately $3 \mathrm{~d}$. Following acclimation, fish and 4001 of water were then removed from the modular system and placed in a fully aerated static tank. Approximately 10000 amoeba cells $\mathrm{l}^{-1}$, isolated from the gills of clinically infected fish according to the method of Howard \& Carson (1993), were added to the aerated static tank with fish and left for $6 \mathrm{~h}$. After the $6 \mathrm{~h}$ infection pulse, the fish and water still containing the amoebae were returned to the modular system. Control fish, held in an identical system, were similarly exposed to sterile seawater.

Blood sampling and analysis. Series I: At 0 (preamoeba addition), 6, 12, 24, 48, 72 and $96 \mathrm{~h}$ arterial blood samples of $500 \mu \mathrm{l}$ were withdrawn via the DA catheters and immediately replaced with an equal volume of Cortland's marine saline (Wolf 1963, containing $160 \mathrm{mmol} \mathrm{l}^{-1} \mathrm{NaCl}$, after Milligan et al. 1991). Arterial $\mathrm{PO}_{2}\left(P_{\mathrm{a}} \mathrm{O}_{2}\right)$ was measured using a Cameron Instrument P-E101 oxygen electrode in a thermostatically controlled chamber connected to a Cameron Instrument Company BGM 200 blood gas analyser and calibrated against air-saturated water and a $2 \% \mathrm{NaSO}_{3}$ (zero) solution. Blood $\mathrm{pH}\left(\mathrm{pH}_{\mathrm{a}}\right)$ was measured using an Activon (AEP 333) combination electrode connected to the blood gas analyser and calibrated to $\pm 0.005 \mathrm{pH}$ units using precision buffer solutions (Radiometer Pacific Pty). Whole blood haemoglobin concentration (Hb) was determined by a commercial spectrophotometric assay (Sigma Diagnostic), and haematocrit 
(HCT) was determined by a microhaematocrit method (Stat Spin III, Norfolk Scientific). Mean cellular haemoglobin concentration (MCHC) was calculated as $\mathrm{Hb} / \mathrm{HCT}$. The remaining whole blood was centrifuged at $10000 \times g$. The total carbon dioxide content $\left(C_{\mathrm{a}} \mathrm{CO}_{2}\right)$ of the plasma was measured using a Capni-con 5 (Cameron Instrument) calibrated against a $20 \mathrm{mmol} \mathrm{l}^{-1}$ $\mathrm{NaHCO}_{3}$ solution. The remaining plasma was frozen at $-20^{\circ} \mathrm{C}$ for later determination of plasma lactate using a spectrophotometric assay (Sigma). Arterial $\mathrm{PCO}_{2}$ $\left(P_{\mathrm{a}} \mathrm{CO}_{2}\right)$ was calculated according to a rearrangement of the Henderson-Hasselbach equation:

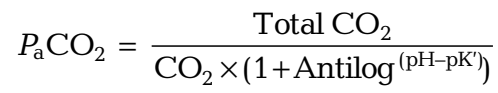

For examination of acid-base status plasma bicarbonate concentration $\left[\mathrm{HCO}_{3}^{-}\right]$was calculated according to:

$$
\left[\mathrm{HCO}_{3}^{-}\right]=\text {Total } \mathrm{CO}_{2}-\left(\alpha \mathrm{CO}_{2} \times P_{\mathrm{a}} \mathrm{CO}_{2}\right)
$$

where total $\mathrm{CO}_{2}$ is the concentration of $\mathrm{CO}_{2}$ measured in the plasma $\left(\mathrm{C}_{\mathrm{a}} \mathrm{CO}_{2}\right), \mathrm{pH}$ is the whole blood $\mathrm{pH}\left(\mathrm{pH}_{\mathrm{a}}\right)$, $\alpha \mathrm{CO}_{2}$ is the solubility of $\mathrm{CO}_{2}$ in plasma at $16^{\circ} \mathrm{C}$ (from Cameron 1986) and $\mathrm{pK}^{\prime}$ is derived from Boutilier et al. (1984).

Fish were lethally anaesthetised in $0.03 \mathrm{ml} \mathrm{l}^{-1}$ clove oil at stages corresponding to sample periods during the experiment to confirm disease status. The second left gill arch was removed and processed using a Tissue-tek II automatic tissue-processing unit. Each sample was then embedded in paraffin wax using a Shandon Histocentre 2, and sectioned at $5 \mu \mathrm{m}$ using a Microm microtome before being stained with haematoxylin and eosin (H\&E) (Thompson \& Hunt 1966).

Series II: Fish $(\mathrm{n}=9)$ were lethally anaesthetised in $0.03 \mathrm{ml} \mathrm{l}^{-1}$ clove oil on Days 0 (pre-amoeba addition), 2, 4, 7, 10 and 16. Caudal blood $\mathrm{pH}, \mathrm{HCT}$ and $\mathrm{Hb}$ were measured as for Series I, and MCHC was calculated. The gills were dissected and processed as for Series I. Histological examination, to assess the level of infection, was quantified as the percent of gill filaments with at least 1 AGD lesion at $\times 100$ magnification, according to the protocol of Roberts \& Powell (2003). To provide reference points for comparison, control fish were sampled on Days 0 (pre-sham-exposure), 2 and 16 , and the above parameters were examined.

Statistical analysis. Due to the small number of catheterised fish that remained viable for the entire duration of the experiment (96 h), data from Series I were analysed only up to $48 \mathrm{~h}$; however, whenever possible, all data, up to and including those for $96 \mathrm{~h}$, have been graphically presented. To assess differences relating to disease status, a 2-way, repeated-measures analysis of variance (ANOVA) was used with time and treatment as fixed factors. When significant inter- active effects were observed within the 2-way, repeated-measures model, planned contrast $t$-tests were used to test for differences between the treatments at each time point. Effects over time within each treatment were tested using a 1-way, repeatedmeasures ANOVA, followed by a Dunnett post hoc comparison to compare the initial $0 \mathrm{~h}$ time point to subsequent time periods. Data from fish exposed to amoebae in Series II were subject to a 1-way ANOVA followed by a Dunnett post hoc test to compare the Day 0 (pre-infection) time point to subsequent days. Lesions were not present on Day 0 (prior to amoeba addition); therefore, these data were not included in the analysis of the percentage of affected filaments. Differences between amoeba-exposed and control fish at reference time points were made using independent $t$-tests. For all statistical analyses, the chosen fiducial limit of significance was 5\%. Values throughout the text are expressed as means \pm 1 SEM. SPSS (version 10.0, SPSS Science) and Sigma Plot (version 6.0, SPSS Science) were used for all data analyses and presentation.

\section{RESULTS}

\section{Series I}

Histological examination of gill sections indicated that typical small AGD lesions with associated amoebae were not present prior to $48 \mathrm{~h}$; however, by $96 \mathrm{~h}$, the extent of infection was more evident, with most fish showing extensive lesion development across the gill surface (Fig. 1). No major significant respiratory effects attributable to amoeba exposure were found within the $48 \mathrm{~h}$ period of actual statistical analysis; however, many of the respiratory parameters did show significant effects occurring over time. In light of this, the majority of the post hoc analyses were made within, rather than between, the 2 treatments. Despite a significant treatment effect $\left(F_{1,3}=47.88, \mathrm{p}=0.006\right)$, arterial $\mathrm{O}_{2}$ tension $\left(P_{\mathrm{a}} \mathrm{O}_{2}\right)$ was highly variable for both AGD and control fish, and, due to equipment failure, data for only a small number of fish from each treatment were utilised for this study (Fig. 2a).

Both total $\mathrm{CO}_{2}$ content $\left(C_{\mathrm{a}} \mathrm{CO}_{2}\right)$ and arterial $\mathrm{pH}\left(\mathrm{pH}_{\mathrm{a}}\right)$ results showed a significant effect of time; however, no significant differences in $\mathrm{C}_{\mathrm{a}} \mathrm{CO}_{2}$ were found for either AGD or control time points compared to each respective time $0 \mathrm{~h}$ baseline (Fig. 2b). Fish exposed to amoebae (AGD) showed a significant increase in $\mathrm{pH}_{\mathrm{a}}$ at $48 \mathrm{~h}$ $\left(F_{1,9}=7.133, \mathrm{p}=0.026\right)$ compared to $0 \mathrm{~h}$ (Fig. 2c). No significant differences in $\mathrm{pH}_{\mathrm{a}}$ were found for controls.

Both haematocrit (HCT) and haemoglobin ( $\mathrm{Hb})$ results showed significant time effects, with both treatment groups showing substantial decreases over the 


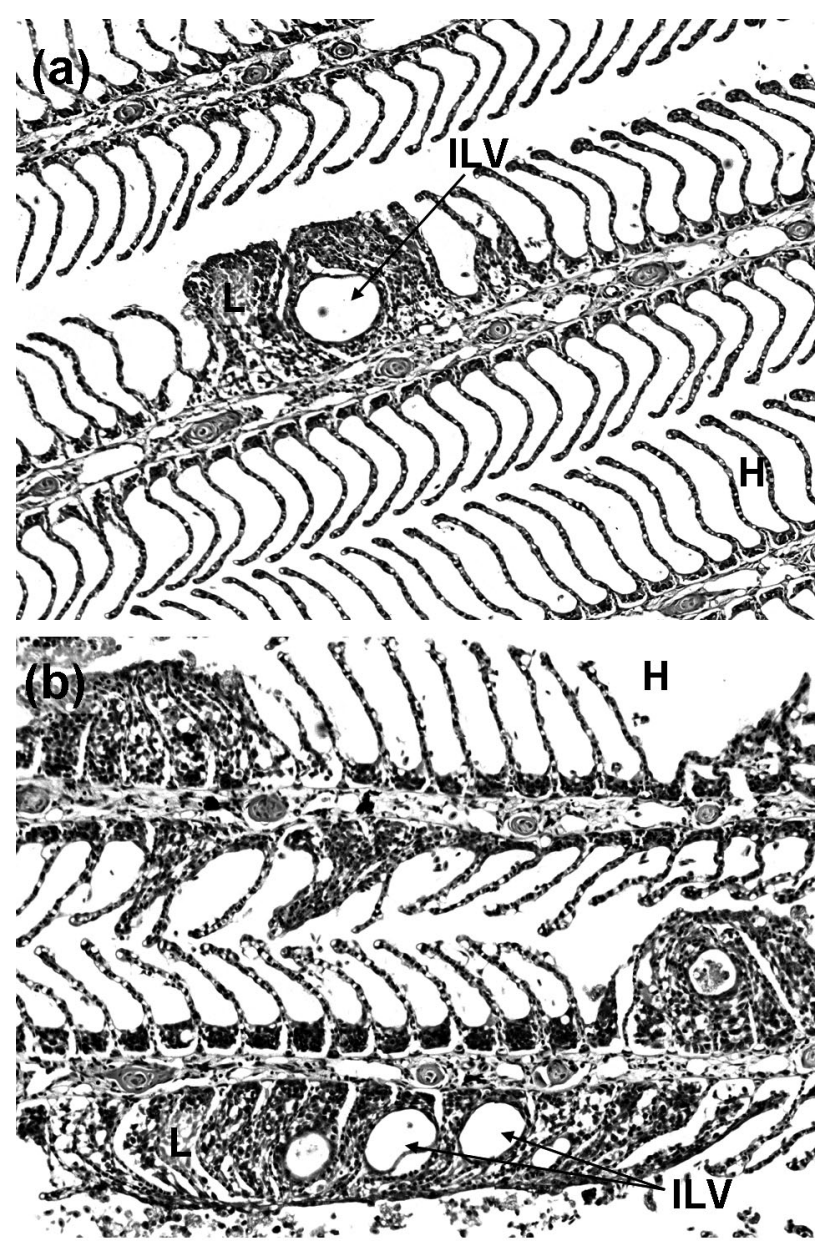

Fig. 1. Salmo salar. Representative histological gill sections taken at (a) $48 \mathrm{~h}$ and (b) $96 \mathrm{~h}$ post-exposure to 10000 amoeba cells $\mathrm{l}^{-1}$, showing fused secondary lamellae resulting in characteristic amoebic gill disease (AGD) lesion (L), healthy secondary lamellae $(\mathrm{H})$ and interlamellar vesicles commonly associated with AGD lesions (ILV). Haematoxylin and eosin stain $(\mathrm{H} \& \mathrm{E})$ (original magnification $\times 40$ )

sampling period. HCT values were significantly lower compared to the time $0 \mathrm{~h}$ baseline for AGD fish at both $24\left(F_{1,5}=7.37, \mathrm{p}=0.042\right)$ and $48 \mathrm{~h}\left(F_{1,5}=10.41, \mathrm{p}=\right.$ 0.023) (Fig. 3a). Control values were significantly depressed from $12 \mathrm{~h}$ onwards $\left(12 \mathrm{~h}, F_{1,4}=27.75, \mathrm{p}=\right.$ $0.006 ; 24 \mathrm{~h}, F_{1,4}=35.06, \mathrm{p}=0.004 ; 48 \mathrm{~h}, F_{1,4}=49.85, \mathrm{p}$ $=0.002)$. Hb values were significantly lower by $48 \mathrm{~h}$ for both the $\operatorname{AGD}\left(F_{1,5}=12.28, \mathrm{p}=0.017\right)$ and control groups $\left(F_{1,5}=22.75, \mathrm{p}=0.005\right)$ (Fig. $\left.3 \mathrm{~b}\right)$. Despite the fact that both $\mathrm{HCT}$ and $\mathrm{Hb}$ values significantly decreased over the course of this experiment, MCHC did not show any time- or treatment-related differences (Fig. 3c).

To give a general assessment of acid-base status of fish during the $48 \mathrm{~h}$ experimental period, $\mathrm{pH}$-bicarbonate diagrams were constructed for each treatment group using $\mathrm{PCO}_{2}$ isopleths to represent the bicarbonate-buffering capacity of the blood, i.e. $\left[\mathrm{HCO}_{3}{ }^{-}\right]$and $\mathrm{pH}$ at a given $\mathrm{PCO}_{2}$ (Powell \& Perry 1997). These diagrams, although not subject to statistical analysis, showed that over the $6 \mathrm{~h}$ period of restricted recirculat-

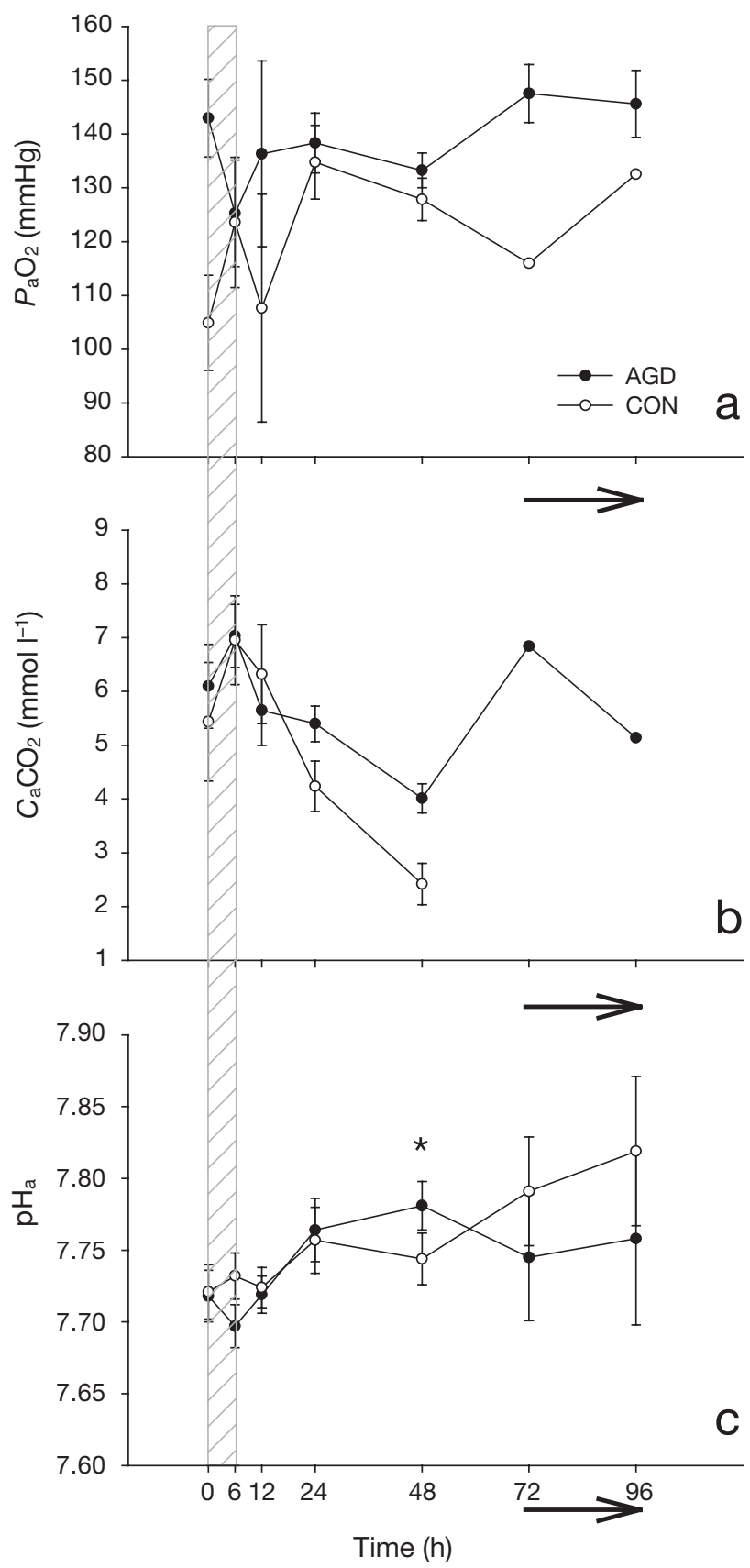

Fig. 2. Salmo salar. Changes in: (a) arterial $\mathrm{O}_{2}\left(P_{\mathrm{a}} \mathrm{O}_{2}\right)$, (b) total $\mathrm{CO}_{2}\left(C_{\mathrm{a}} \mathrm{CO}_{2}\right)$ and $(\mathrm{c})$ arterial $\mathrm{pH}\left(\mathrm{pH}_{\mathrm{a}}\right)$, following $6 \mathrm{~h}$ exposure (hatched area) to 10000 amoeba cells $\mathrm{l}^{-1}$ (AGD) or sterile seawater $(\mathrm{CON})$. Within treatments an asterisk denotes a significant difference from the corresponding $0 \mathrm{~h}$ time point $(p<0.05)$. Values are means \pm SE. Points above arrow (post $48 \mathrm{~h}$ ) were not included in the statistical analysis due to low replication 
ing water volume, both treatment groups developed an acidosis that appeared to be respiratory in nature (Fig. 4a,b). Once the initial water volume was restored, the acidosis was corrected for both groups of fish. Fish exposed to amoebae showed a general trend towards

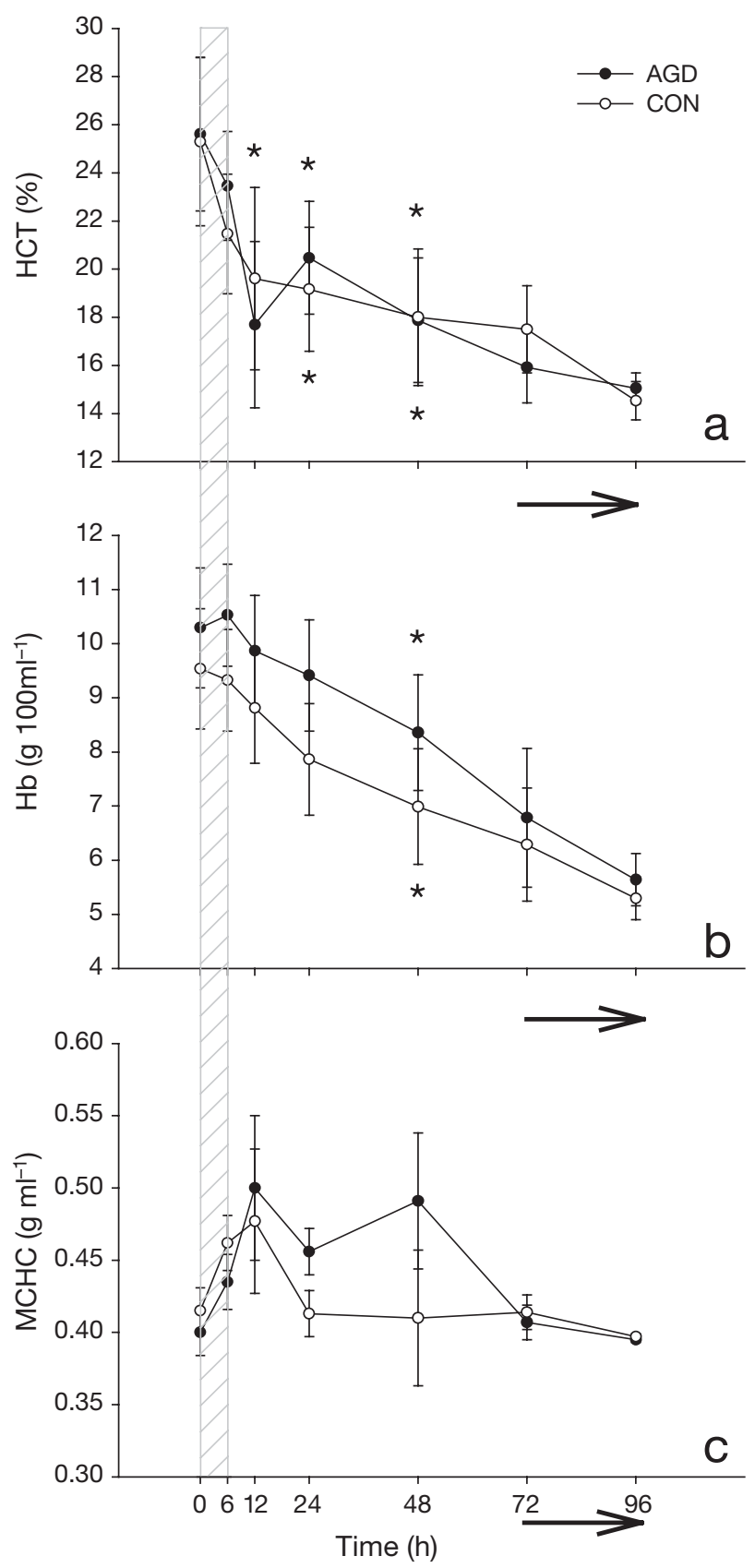

Fig. 3. Salmo salar. Changes in: (a) haematocrit (HCT), (b) haemoglobin ( $\mathrm{Hb})$ and (c) mean cellular haemoglobin concentration (MCHC) following $6 \mathrm{~h}$ exposure (hatched area) to 10000 amoeba cells $~^{-1}$ (AGD) or sterile seawater (CON). Within treatments an asterisk denotes a significant difference from the corresponding $0 \mathrm{~h}$ time point $(\mathrm{p}<0.05)$. Values are means \pm SE. Points above arrow (post $48 \mathrm{~h}$ ) were not included in the statistical analysis due to low replication both mixed respiratory and metabolic alkalosis, indicated by lower $\left[\mathrm{HCO}_{3}{ }^{-}\right]$and $\mathrm{PCO}_{2}$ accompanied by an increased $\mathrm{pH}_{\mathrm{a}}$. Control fish also demonstrated lower $\left[\mathrm{HCO}_{3}{ }^{-}\right]$and $\mathrm{PCO}_{2}$; however, despite this, $\mathrm{pH}_{\mathrm{a}}$ did not change, suggesting that control fish underwent mixed metabolic acidosis and respiratory alkalosis. Plasma lactate did not change over time or with amoeba exposure (data not presented).

\section{Series II}

Results showed that over the course of the experiment caudal blood $\mathrm{pH}$ of exposed fish changed significantly over the $16 \mathrm{~d}$ period $\left(F_{5,47}=7.79, \mathrm{p}<0.001\right)$. Initially there was a significant increase from Day 0 to Day $2(\mathrm{p}=0.008)$, and again to Day 7 ( $\mathrm{p}=0.032)$ (Fig. 5a). From Day 7, however, it was evident that $\mathrm{pH}$ began to decrease. Although control $\mathrm{pH}$ values were similar to those of the exposed group at both 0 ( $\mathrm{p}=$

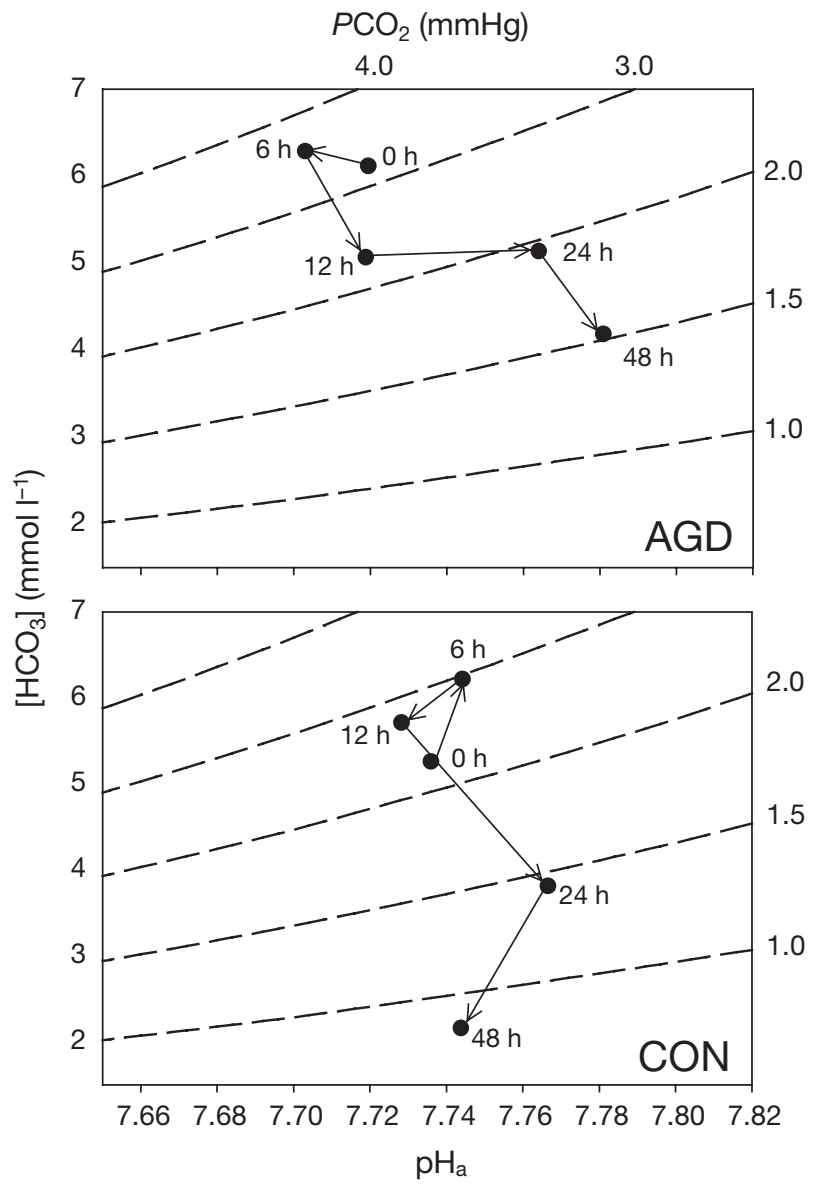

Fig. 4. Salmo salar. Plasma $\left[\mathrm{HCO}_{3}{ }^{-}\right]$versus arterial $\mathrm{pH}\left(\mathrm{pH}_{\mathrm{a}}\right)$ diagram with $\mathrm{PCO}_{2}$ isopleths and the in vivo changes in extracellular acid-base status following $6 \mathrm{~h}$ exposure to 10000 amoeba cells $1^{-1}$ (AGD) or sterile seawater (CON). Mean values only for data up to $48 \mathrm{~h}$ presented 
0.978) and $2 \mathrm{~d}(\mathrm{p}=0.054)$, by Day 16, $\mathrm{pH}$ of the exposed group was significantly lower compared to that of controls $(\mathrm{p}=0.001)$.

HCT values of exposed fish also significantly changed over the sampling period $\left(F_{5,47}=3.07, \mathrm{p}=\right.$ 0.018), with a significant increase evident by Day 16
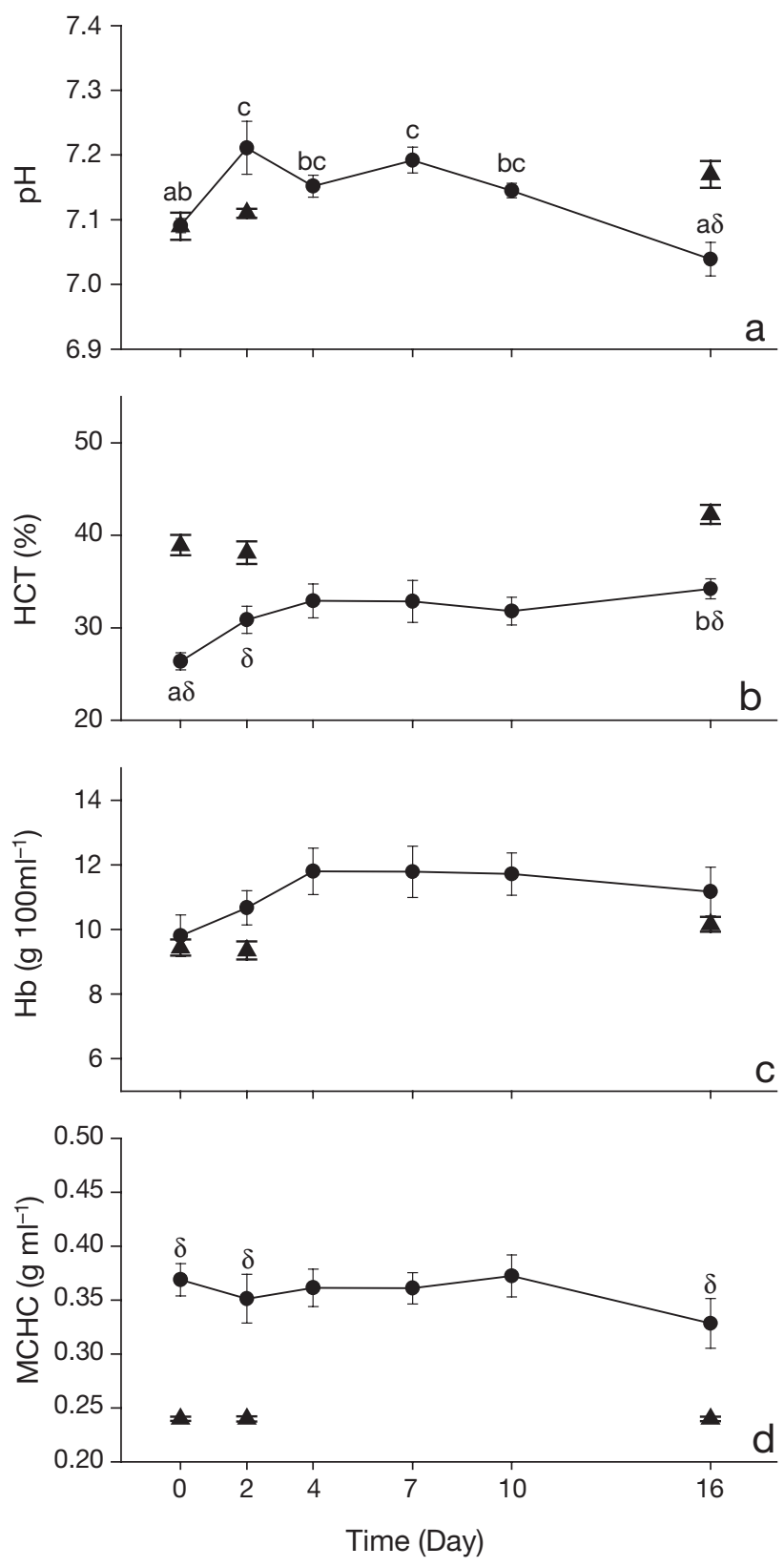

Fig. 5. Salmo salar. Changes in caudal blood: (a) $\mathrm{pH}$, (b) haematocrit (HCT), (c) haemoglobin (Hb) and (d) mean cellular haemoglobin concentration (MCHC), following $6 \mathrm{~h}$ exposure to 10000 amoeba cells $\mathrm{l}^{-1}(\mathrm{AGD}, \mathbf{0})$ or sterile seawater $(\mathrm{CON}, \boldsymbol{\Delta})$. Within the exposed group, values (mean \pm $\mathrm{SE})$ that share common letters are not significantly different $(p>0.05) . \delta$ denotes a significant difference between AGD and CON groups at the same time point
( $p=0.011$ ) (Fig. $5 b)$. The Hb value did not significantly change over the sampling period $\left(F_{5,47}=1.34, \mathrm{p}=\right.$ 0.264) (Fig. 5c). Similarly, MCHC data remained unchanged over the duration of the experiment $\left(F_{5,47}=\right.$ 0.72, $p=0.607$ ) (Fig. 5d). HCT of the control fish was significantly elevated at all reference time points compared to exposed fish (Day 0, p $<0.001$; Day 2, p = 0.002 ; Day $16, \mathrm{p}<0.001)$. Hb was not significantly different between the treatments, and, as a result, $\mathrm{MCHC}$ values for controls were significantly lower compared to those for exposed fish at all reference time points (Day 0, p $<0.001$; Day 2, p $<0.001$; Day 16, $\mathrm{p}<0.001$ ).

Histological analysis of gill sections indicated that gill pathology typical of AGD was evident from Day 2, when $26.05 \pm 4.52 \%$ of gill filaments were affected with AGD. Over the duration of the experiment the number of AGD-affected filaments increased significantly over time $\left(F_{4,29}=22.31, \mathrm{p}<0.001\right)$. Significant differences from Day 2 were seen at Day 7 (54.3 \pm $6.7 \%, \mathrm{p}=0.005)$, Day $10(56.4 \pm 5.1 \%, \mathrm{p}=0.001)$ and Day 16 (90.6 $\pm 4.5 \%, \mathrm{p}<0.001)$ (Fig. 6). By Day 4 , the percentage of affected filaments had increased to 43.8 $\pm 4.9 \%$; however, this was not found to be statistically significant compared to Day $2(\mathrm{p}=0.085)$. AGD lesions were not present in control fish.

\section{DISCUSSION}

Although there are many pathological studies regarding disease and disease development, there is very little concerning the physiological consequences of disease status and the physiological changes which occur during the progression of an actual infection. In

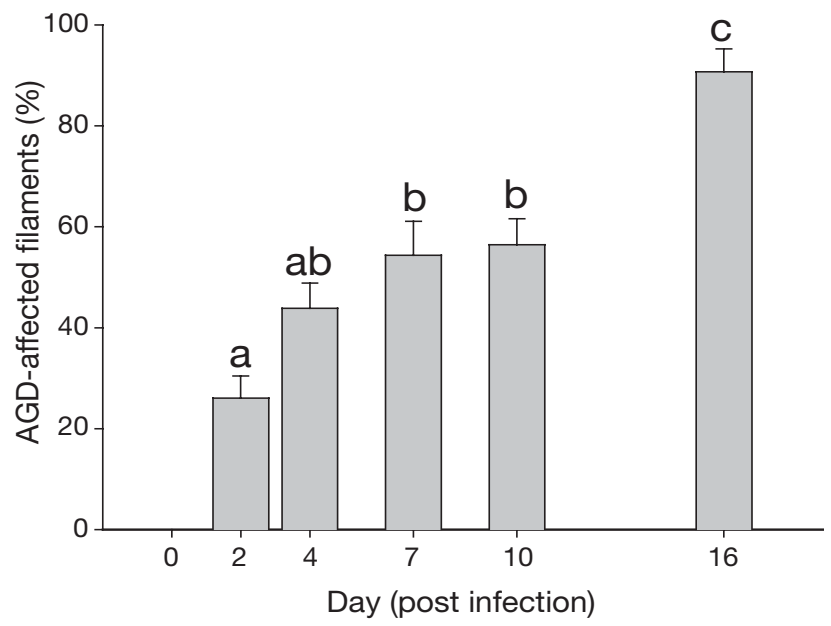

Fig. 6. Salmo salar. Changes in the percentage of AGDaffected gill filaments following $6 \mathrm{~h}$ exposure to 10000 amoeba cells $\mathrm{l}^{-1}$. Values (means $\pm \mathrm{SE}$ ) that share common letters are not significantly different $(p>0.05)$ 
many studies the mechanisms underlying mortality are often inferred from the pathological findings and are not commonly measured or investigated. AGD for instance, which only affects the gill, was initially thought to cause respiratory failure; however, the combined results of Powell et al. (2000), Fisk et al. (2002) and the present study do not support this hypothesis. In this study, significant respiratory changes in response to AGD occurred at approximately $7 \mathrm{~d}$ postinfection and coincided with a significant increase in the percentage of gill filaments displaying AGD lesions. Therefore, it is not surprising that no major significant treatment effects were found in Series I. Histological analysis of gills taken from Series I fish revealed that AGD lesions were present by $48 \mathrm{~h}$; however, these lesions, often seen in association with amoebae, were small and few in number. Therefore, considering the respiratory changes seen in Series II fish at the same time point, the lesions were probably not at a level sufficient to induce pathological respiratory effects.

Arterial $\mathrm{pH}\left(\mathrm{pH}_{\mathrm{a}}\right)$ in fish exposed to amoebae (Series I) was significantly elevated at $48 \mathrm{~h}$ compared to the $0 \mathrm{~h}$ time point. This also occurred in fish from Series II, with a significant elevation in caudal blood $\mathrm{pH}$ by Day 2. These results suggest that following exposure to amoebae fish initially undergo alkalosis. Examination of the acid-base diagram from fish in Series I exposed to amoebae indicated that this initial alkalosis, which appeared to be primarily respiratory in nature, may have developed from hyperventilation, since $\mathrm{PCO}_{2}$ values steadily dropped from $6 \mathrm{~h}$ onwards. In a previous study, ventilation rates between AGDaffected and naïve salmon were not found to be significantly different (Powell et al. 2000); however, while ventilation rates were not recorded in this study, it is possible that the addition of amoebae to the system and subsequent attachment to secondary gill lamellae may have initially stimulated mucus production and hyperventilation.

Increased mucus production, via significant elevations in mucous cell numbers, has also been noted in association with AGD (Munday et al. 1990, Nowak \& Munday 1994, Adams \& Nowak 2003, Roberts \& Powell 2003), and, although gill mucus production does not appear to greatly influence $\mathrm{O}_{2}$ uptake in rainbow trout exposed to a chemical gill irritant, there is evidence to suggest that it does impair $\mathrm{CO}_{2}$ excretion (Powell \& Perry 1996, 1997, 1999), and this could lead to an acute acid-base disturbance. Although caudal blood pH was significantly elevated in Series II fish by Day 2, it appeared to fall from Day 7 onwards and consistently decreased over the remainder of the sampling period. Additionally, the percentage of lesions affecting primary gill filaments became signifi- cantly elevated, compared to Day 2 (onset of disease), from Day 7 onwards. The apparent acidosis that developed in Series II fish may therefore be related to a decrease in functional gill surface area and indicate the initial development of the characteristic acidosis previously reported for AGD-affected salmon (Powell et al. 2000, Powell \& Nowak 2003). Powell et al. (2000) found that compared to naïve individuals, AGDaffected salmon displayed a significantly elevated $\mathrm{PCO}_{2}$ and significantly lower $\mathrm{pH}$ and $\mathrm{PO}_{2}$, which indicated respiratory acidosis prior to a graded hypoxic challenge. Although it was shown that AGD-affected fish were acidotic, Powell et al. (2000) found that even during graded hypoxia, to a level of approximately $25 \%$ saturation, the presence of AGD did not contribute to respiratory failure, despite the fact that gas transfer was impaired under normoxic conditions. It was therefore suggested that infected fish were able to defend respiration via physiological mechanisms such as increased blood flow and perfusion within the gill.

The actual effect of AGD lesions on gill blood flow is not currently understood; however, pathological studies of AGD have shown that amoeba presence and attachment to gill filaments initially results in hyperplasia of epithelial cells (Adams \& Nowak 2003). Epithelial cells play a prominent role in respiratory gas transfer (Lin \& Randall 1995); thus, any alterations in epithelial thickness can potentially decrease functional surface area for transfer of respiratory gases. Therefore, an increase in the blood-water diffusion distance may be expected to influence normal respiratory processes and induce pathological changes (Perry \& McDonald 1993). There is evidence to suggest that the gill is not fully ventilated or equally perfused at any one time. In rainbow trout, Booth (1978) suggested that only about $60 \%$ of all lamellae are perfused at rest. Therefore, there is substantial scope for recruitment of previously under-perfused filaments (Booth 1979), recruitment or redistribution of blood flow to peripheral lamellae (Booth 1979, Olson 1979), and perfusion of distal areas of the lamellae (Farrell et al. 1980, Tuurala et al. 1984) via hyperventilation (Smith \& Jones 1982, Jensen et al. 1993) and/or cardiovascular adjustments (Booth 1979, Soivio \& Tuurala 1981) to compensate for any reductions or impairment of normal functional gill surface area. In this study, AGD lesions were shown to affect $>90 \%$ of primary lamellae by Day 16; therefore, considering that no major respiratory disturbance was noted, it is possible that lamellar recruitment mediated any respiratory compromise caused by AGD lesions, thus allowing fish to defend respiration.

It is possible that increased $\mathrm{HCT}$ and $\mathrm{Hb}$ levels also mediate respiratory disturbance in AGD-affected 
salmon. Arterial blood was repeatedly taken from fish in Series I, and this sampling regime was most likely responsible for the significant decreases seen in both haematocrit and haemoglobin. Fish exposed to amoebae from Series II, however, displayed significantly elevated haematocrit levels at 16 d post-infection. $\mathrm{Hb}$ also appeared to increase following amoeba exposure; however, this response reached a plateau at Day 4, and no significant differences were found with respect to the pre-Day 0 sample. HCT and Hb both directly influence the ability of the blood to carry $\mathrm{O}_{2}$ and are a major determinant of arterial $\mathrm{O}_{2}$ content (Gallaugher \& Farrell 1998). Therefore, significant HCT elevations may help to mitigate any possible $\mathrm{O}_{2}$ uptake limitations, which potentially occur at the level of the gill. For reasons unknown, control reference points were significantly elevated compared to the experimental treatment; however, as control $\mathrm{Hb}$ values were similar to those of the AGD group, it is possible that increased HCT levels relate to red blood cell swelling, as indicated by the significantly lower $\mathrm{MCHC}$ values.

In conclusion, this study was aimed to track the respiratory responses and, more specifically, the onset of acidosis in Atlantic salmon exposed and subsequently infected with Neoparamoeba pemaquidensis, the causative agent of AGD. Results have suggested that the previously seen respiratory acidosis occurs when functional gill surface area becomes compromised beyond the point of respiratory defense that may include greater perfusion or a redistribution of blood within the gill and elevations in both $\mathrm{HCT}$ and $\mathrm{Hb}$. In this study, the characteristic acidosis appeared to coincide with a time period in which a significant increase in the number of affected gill filaments was seen; however, the functional gas-exchange abilities of lesioned areas still require further investigation. Although fish in this study showed up to $90 \%$ AGDaffected filaments, the corresponding respiratory results do not reflect major acid-base disturbance. Experimental infections of AGD are typically far more aggressive compared to wild infections due to the increased pathogen loading that fish in culture conditions would not normally experience (Adams \& Nowak 2001). Although the precise cause of AGD-associated mortality remains unknown, this, along with the results from the present study, suggests that AGDassociated mortality in cultured fish is not caused by respiratory failure. Powell et al. $(2002 a, b)$ have suggested AGD may possibly be associated with cardiovascular dysfunction, perhaps due in part to possible cytopathic effects of the amoebae (Butler \& Nowak 2004); however, the actual cardiovascular responses of Atlantic salmon to infection, or extracellular amoeba products, have not been examined.
Acknowledgements. The authors gratefully thank M. Attard for help with fish husbandry, the UTAS AGD research group for technical support, N. Moltschaniwskyj for statistical advice and B. Nowak for advice on the manuscript. This work formed part of a project of Aquafin CRC and received funds from the Australian Government's CRCs Program, the Fisheries R\&D Corporation and other CRC participants. Thank you also to the 2 anonymous referees for helpful comments and suggestions.

\section{LITERATURE CITED}

Adams MB, Nowak BF (2001) Distribution and structure of lesions in the gills of Atlantic salmon, Salmo salar L., affected with amoebic gill disease. J Fish Dis 24:535-542

Adams MB, Nowak BF (2003) Amoebic gill disease: sequential pathology in cultured Atlantic salmon, Salmo salar L. J Fish Dis 26:601-614

Adams MB, Nowak BF (2004) Experimental amoebic gill disease of Atlantic salmon, Salmo salar L.: further evidence for the primary pathogenic role of Neoparamoeba sp. (Page, 1987). J Fish Dis 27:105-113

Booth JH (1978) The distribution of blood flow in gills of fish: application of a new technique to rainbow trout (Salmo gairdneri). J Exp Biol 73:119-129

Booth JH (1979) The effects of oxygen supply, epinephrine and acetylcholine on the distribution of the blood flow in trout gills. J Fish Biol 83:31-39

Boutilier RG, Heming TA, Iwama GK (1984) Appendix: physiochemical parameters for use in fish respiratory physiology. In: Hoar WS, Randall DJ (eds) Fish physiology. Academic Press, London, p 403-430

Butler R, Nowak BF (2004) In vitro interactions between Neoparamoeba sp. and Atlantic salmon epithelial cells. J Fish Dis 27:343-349

Cameron JN (1986) Principles of physiological measurement. Academic Press, London

Dykova, I, Figueras, A, Novoa B, Casal JF (1998) Paramoeba sp., an agent of amoebic gill disease of turbot Scopthalmus maximus. Dis Aquat Org 33:137-141

Dykova I, Figueras A, Zilberg D (2000) Neoparamoeba Page, 1987: light and electron microscopic observations on six strains of different origin. Dis Aquat Org 43:217-223

Farrell AP, Sobin SS, Randall DJ, Crosby S (1980) Intralamellar blood flow pattern in fish gills. Am J Physiol 239:R428-R436

Fisk DM, Powell MD, Nowak BF (2002) The effects of amoebic gill disease and hypoxia on survival and metabolic rate of Atlantic salmon (Salmo salar). Bull Eur Assoc Fish Pathol 22:190-194

Gallaugher P, Farrell AP (1998) Hematocrit and blood oxygen-carrying capacity. In: Perry SF, Tufts BL (eds) Fish respiration. Academic Press, London, p 185-219

Howard T, Carson J (1993) Verification of Paramoeba species are consistently associated with gill damage in fish affected with amoebic gill disease. In: Valentine P (ed) Proceedings of the Saltas research and development review seminar. Salmon Enterprises of Tasmania, Dover, Tasmania, p 69-80

Jensen FB, Nikinmaa M, Weber RE (1993) Environmental perturbations of oxygen transport in teleost fishes: causes, consequences and compensations. In: Rankin JC, Jensen FB (eds) Fish ecophysiology. Chapman \& Hall, London, p 161-179

Kent ML, Sawyer TK, Hedrick RP (1988) Paramoeba pemaquidensis (Sarcomastigophora: Paramoebidae) in- 
festation of the gills of coho salmon Oncorhynchus kisutch reared in sea water. Dis Aquat Org 5:163-169

Lin H, Randall D (1995) Proton pumps in fish gills. In: Shuttleworth TW, Wood CM (eds) Cellular and molecular approaches to fish ionic regulation. Academic Press, San Diego, p 229-255

Milligan LC, McDonald GD, Prior T (1991) Branchial acid and ammonia fluxes in response to alkalosis and acidosis in two marine teleosts: coho salmon (Oncorhynchus kisutch) and starry flounder (Platichthys stellatus). Physiol Zool 64: 169-192

Munday BL, Foster CK, Roubal FR, Lester FGJ (1990) Paramoebic gill infection and associated pathology of Atlantic salmon, Salmo salar, and rainbow trout, Salmo gairdneri, in Tasmania. In: Perkins FO, Cheng TC (eds) Pathology in marine science. Academic Press, San Diego, CA, p 215-222

Munday BL, Lange $\mathrm{K}$, Foster C, Lester RJG, Handlinger J (1993) Amoebic gill disease of sea-caged salmonids in Tasmanian waters. Tasman Fish Res 28:14-19

Munday BL, Zilberg D, Findlay V (2001) Gill disease of marine fish caused by infection with Neoparamoeba pemaquidensis. J Fish Dis 24:497-507

Nowak BF, Munday BL (1994) Histology of gills of Atlantic salmon during the first few months following transfer to sea water. Bull Eur Assoc Fish Pathol 14:77-81

Nowak BF, Carson J, Powell MD, Dykova I (2002) Amoebic gill disease in the marine environment. Bull Eur Assoc Fish Pathol 22:144-147

Olson KR (1979) The linear cable theory as a model of gill blood flow. J Theor Biol 81:377-388

Perry SF, McDonald G (1993) Gas exchange. In: Evans DH (ed) The physiology of fishes. CRC Press, Boca Raton, FL, p 251-278

Powell MD, Nowak BF (2003) Acid-base and respiratory effects of confinement in Atlantic salmon affected with amoebic gill disease. J Fish Biol 62:51-63

Powell MD, Perry SF (1996) Respiratory and acid-base disturbances in rainbow trout (Oncorhynchus mykiss) blood during exposure to chloramine- $\mathrm{T}$, paratoluene-

Editorial responsibility: Wolfgang Körting,

Hannover, Germany sulphonamide and hypochlorite. Can J Fish Aquat Sci 53: 701-708

Powell MD, Perry SF (1997) Respiratory and acid-base disturbances in rainbow trout blood during exposure to chloramine-T under hypoxia and hyperoxia. J Fish Biol 50: 418-428

Powell MD, Perry SF (1999) Cardio-respiratory effects of chloramines-T exposure in rainbow trout. Exp Biol Online $4: 5$

Powell MD, Fisk D, Nowak BF (2000) Effects of graded hypoxia on Atlantic salmon infected with amoebic gill disease. J Fish Biol 57:1047-1057

Powell MD, Forster ME, Nowak BF (2002a) Vascular hypertension associated with amoebic gill disease affected Atlantic salmon (Salmo salar) in Tasmania. Bull Eur Assoc Fish Pathol 22:328-333

Powell MD, Nowak BF, Adams MB (2002b) Cardiac morphology in relation to amoebic gill disease history in Atlantic salmon, Salmo salar L. J Fish Dis 25:209-215

Roberts SD, Powell MD (2003) Comparative ionic flux and gill mucous cell histochemistry: effects of salinity and disease status in Atlantic salmon (Salmo salar L.). Comp Biochem Physiol A 134:525-537

Smith FM, Jones DR (1982) The effect of changes in blood oxygen-carrying capacity on ventilation volume in the rainbow trout (Salmo gairdneri). J Exp Biol 97:325-334

Soivio A, Tuurala H (1981) Structural and circulatory responses to hypoxia in the secondary lamellae of Salmo gairdneri gills at two temperatures. J Comp Physiol 145:37-39

Soivio A, Nyholm K, Westman K (1975) A technique for repeated sampling of the blood of individual resting fish. J Exp Biol 62:207-217

Thompson SW, Hunt RD (1966) Selected histochemical and histopathological methods. Charles Thomas, Springfield, IL

Tuurala H, Pärt P, Nikinmaa M, Soivio A (1984) The basal channels of secondary lamellae in Salmo gairdneri gills a non-respiratory shunt. Comp Biochem Physiol A 79: $35-39$

Wolf K (1963) Physiological saline's for freshwater fishes. Prog Fish Cult 25:135-140

Submitted: December 8, 2004; Accepted: March 23, 2005

Proofs received from author(s): September 20, 2005 